\title{
REVIEW
}

\section{Occupation and gastric cancer}

\author{
A Raj, J F Mayberry, T Podas
}

Postgrad Med J 2003;79:252-258

Gastric cancer is a cause of significant morbidity and mortality. There are several risk factors, with occupation emerging as one of these. There is considerable evidence that occupations in coal and tin mining, metal processing, particularly steel and iron, and rubber manufacturing industries lead to an increased risk of gastric cancer. Other "dusty" occupations-for example, wood processing, or work in high temperature environments have also been implicated but the evidence is not strong. The mechanism of pathogenesis of gastric cancer is unclear and the identification of causative agents can be difficult. Dust is thought to be a contributor to the pathological process, but well known carcinogens such as $\mathrm{N}$-nitroso compounds have been detected in some environments. Further research on responsible agents is necessary and screening for detection of precursor gastric cancer lesions at the workplace merits consideration.

See end of article for authors' affiliations

Correspondence to: Dr Anita Raj, Gastrointestinal Research Unit, Leicester General Hospital, Gwendolen Road, Leicester LE2 4TF, UK; anitaaraj@aol.com

Submitted 30 April 2002 Accepted

25 November 2002

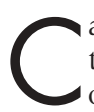
ancer incidence and mortality rose during the 20th century to become a leading cause of death. Until 1985, ${ }^{2}$ gastric cancer was the most common cancer worldwide with an annual incidence of nearly 700000 cases. ${ }^{3}$ More recently this has declined and has been surpassed by lung cancer. ${ }^{3}$

Much research has been conducted on external risk factors with several studies looking at occupation. Most available data on occupational exposure and cancer concern lung cancer. Only recently has gastric cancer been considered an occupational hazard. Here we have highlighted some of this research and critically assessed the results as well as identifying high risk occupations.

\section{EPIDEMIOLOGICAL CONSIDERATIONS}

The pathogenesis of gastric cancer appears multifactorial. Geography ${ }^{4}$ and diet play a part ${ }^{5}$; smoking is not only an important risk factor, but the type of tobacco might also influence the site of carcinoma development. ${ }^{7}$ Social class and socioeconomic parameters ${ }^{8}$ are significant risk factors and may influence survival. ${ }^{9}$ Religion has been associated with a reduced risk, possibly through dietary restrictions. ${ }^{10}$ A greater incidence has been reported in males, ${ }^{11}$ and researchers have also reported genetic links with ethnicity ${ }^{12}{ }^{13}$ and blood group $\mathrm{A},{ }^{14}{ }^{15}$ which confers up to $16 \%$ higher risk. The possibility of family clustering was investigated by several studies. ${ }^{17}$ Despite limitations, including incomplete data collection, an early review pointed towards aggregation of gastric

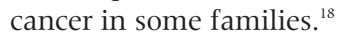

There is considerable regional variation within high risk areas. ${ }^{19} 20$ Migration from high to low risk regions reduces the risk in second or third generations, providing the dietary habits of the host country are adopted. ${ }^{5}$ This lends weight to the hypothesis that environmental factors operate early in life. ${ }^{21}$ The discovery of Helicobacter pylori has given further impetus to the search for a cause of gastric cancer. ${ }^{22} 23$

Prevalence of gastric cancer obeys social stratification patterns. Occupations often have a definable social class, and this is frequently used to explain positive associations between cancer and occupation.

In view of the long latency of the carcinogenic process and the difficulties it imposes on research, interest has focused on early markers and risk factors. Such markers include atrophic gastritis and intestinal metaplasia. ${ }^{24-26}$ Others can be seen at a histochemical level. A significant risk predictor is the anomalous expression of blood group antigens in mucin, especially those of the Lewis group. ${ }^{27}$ Other markers such as pepsinogens are currently under investigation and may help further risk identification.

\section{SOME HISTOLOGICAL CONSIDERATIONS}

The majority of gastric neoplasms are adenocarcinomas, which can be subdivided with each subtype exhibiting different behaviour. The most widely used histological classification was proposed by Lauren. ${ }^{28}$ He defined two main types: The intestinal or "epidemic" form and a diffuse variety. The former is more prevalent in the elderly and men. It has a better prognosis and is more frequent in high risk areas. ${ }^{29-31}$ The diffuse adenocarcinoma has a more uniform incidence..$^{20}$ It is poorly differentiated with a worse prognosis and its incidence, unlike the intestinal variety, has shown no tendency to decline.

Histological type is not usually recorded on death certificates which make collection and evaluation of data more difficult. As a result, few studies have investigated gastric cancer histology in relation to occupation. In studies that analysed histological type, the intestinal variety was most common. ${ }^{32}$ Further progress in our understanding of the carcinogenic process is being directed towards histological precursors, such as intestinal metaplasia and atrophic gastritis. There are

Abbreviations: BRMA, British Rubber Manufacturer's Association; IARC, International Agency for Research on Cancer 


\section{Risk of gastric cancer and occupation}

High
- Carpenters.
- Steelworkers.
- Tin miners.
Increased
- Chemical industry workers.
- Coal miners.
- Coke plant workers.
- Oil refinery workers.
- Rubber manufacturing.
Possible
- Agricultural workers.
- Goldminers.
- Lorry and coach drivers.
- Jewellery workers.
- Metal (and components) manufacturers.

hardly any data linking occupational exposures with these conditions.

\section{PATHOGENESIS}

Few theories about the pathogenesis of gastric cancer have developed over the years.

Polyunsaturated fats have been suggested as possible initiators or modulators. ${ }^{33}$ They may contribute to the formation of lipid peroxides in the stomach, which in turn could damage the gastric mucosa. Increased tissue levels of arachidonic acid can be produced through consumption of polyunsaturated fats. During this process "active" oxygen is generated and this may have a role in carcinogenesis, by damaging DNA.

Correa's $N$-nitrosoamine unifying theory has been developed over several years. ${ }^{6}{ }^{12}{ }^{34}$ It postulates that gastric carcinoma is the end result of a series of mutations and cell transformations that begin in the first decade of life. Mutagens responsible are thought to be nitroso compounds formed in the upper gastrointestinal tract. This process can be accelerated by the lack of micronutrients such as ascorbic acid or carotenoids, an excessively salty diet, or infections, for example, $\mathrm{H}$ pylori. ${ }^{34}$ All these factors appear to act on a common pathogenic pathway. For example, a reduction in acid production results in increased formation of $\mathrm{N}$-nitroso compounds by bacteria in the upper gastrointestinal tract. It is of note that these compounds can also be found in some occupational environments. ${ }^{35}$

Nitroso compounds can be formed in the stomach of humans by interaction of nitrite or nitrogen oxides and nitrosatable amines, such as citrulline, arginine, methylguanidine, etc. Intragastric $\mathrm{N}$-nitroso compound formation has been suspected in carcinogenesis. ${ }^{36}{ }^{37}$ The development of a nitrosamine-sensitive detector in 1975 demonstrated a complex pattern of human exposure, occurring via different routes. ${ }^{38}$

Endogenous exposure occurs through the uptake of amine precursors and formation of carcinogenic compounds in the saliva and gastric juice. ${ }^{39}$ Nitrite is abundant in the food chain, and is used both as a colouring agent and preservative. It has also been found in the saliva of people eating certain vegetables.$^{40}$ Nitrates in fertilisers can be found in agricultural products and are converted to nitrite at body temperature. Intragastric formation of nitrosamines is blocked up to $80 \%$ by ascorbic acid or up to $50 \%$ by tocopherols. ${ }^{39}$

Exogenous exposure can be related to lifestyle (tobacco, food, cosmetics, drugs, etc) or occupation. This latter category is the largest known exogenous source. ${ }^{35}$ Occupations with high levels of $\mathrm{N}$-nitrosamines in the work environment include:
- Rubber industry.

- Metal industry: N-nitrosodiethanolamine has been found in cutting fluids which contain diethanolamine and nitrite as anticorrosives. Cutting oil mist can be inhaled, penetrate the skin, or contaminate other products.

- Leather tanning industry: $\mathrm{N}$-nitrosodimethylamine formation has been attributed to chemicals used in the depilation process.

- Environmental exposure to preformed nitrosamines: Contact with cosmetics, drugs, agricultural chemicals, rubber products, and packaging materials can result in low level exposure to $\mathrm{N}$-nitrosamines.

At a cellular level, the mechanisms responsible for cancer are unclear. Current views suggest that increased mitogenesis promotes mutagenesis. ${ }^{41}$ Yet, not all such substances are directly mutagenic and so carcinogenesis may follow more than one path. ${ }^{42}$

\section{STUDY METHODOLOGY AND CLASSIFICATION OF OCCUPATIONS}

Good epidemiological studies are not easy. The majority of surveys have been based on death certificates, which are susceptible to diagnostic errors or miscertification, ${ }^{44-46}$ or cancer registry information. Both are affected by discrepancies that exist between clinical and histologically confirmed diagnoses. Few studies provide histopathological data and consequently a proportion of deaths may have been wrongly attributed.

The search for an association between occupation and gastric cancer has been based on either general population studies or cohort and case-control studies of specific occupations in industries.

Classification of occupations is rather vague and descriptive in early studies. As knowledge about risks accumulates, it has become more structured and linked to working practices and exposure to specific agents. Use of internationally accepted classification of occupations has remedied some problems, although new techniques and agents in industrial processes will continue to frustrate accurate assessment of risk.

Early occupational surveys took little account of confounding elements such as diet, smoking, etc. Therefore, estimates of risks can differ widely between similar studies. As a result of these weaknesses occupational risks of gastric cancer remain the subject of debate.

\section{METAL AND MINING INDUSTRY} Steel foundry workers

The International Agency for Research on Cancer (IARC) concluded that occupational exposure to iron in steel and iron foundries is probably carcinogenic. ${ }^{47}$ Analysis of a UK cohort of 10438 workers from 10 different foundries concluded there was a significant excess of gastric cancer. ${ }^{47-49}$ Risk was highest for those working in the foundry area and more specifically in "furnace" related occupations.

\section{Nickel and copper workers}

In a thorough review the IARC concluded that nickel is carcinogenic, ${ }^{50}$ with specific processes, such as nickel refining, carrying higher carcinogenic risk. ${ }^{51}$ Water insoluble nickel salts are retained in mucous membranes longer than water soluble salts. Consequently workers exposed during smelting have a higher exposure than those working in electrolysis.

In 1990, an international committee examined the evidence for the risk of gastric cancer in 10 cohort studies in the USA, UK, Canada, Norway, Finland, and New Caledonia. ${ }^{52}$ None supported an increased risk. However, data from four USSR refineries, not included in the committee's analysis, suggested an increased risk of gastric cancer. Karjalainen et al found a 
slightly increased risk of gastric cancer among a cohort of workers at a copper/nickel smelter and nickel refinery in Finland..$^{53}$

\section{Lead exposure}

A high incidence of gastric cancer among 4500 workers of a battery plant has been associated with lead exposure. ${ }^{54}$ Studies in other industries on smaller lead-exposed populations, have failed to confirm this link..$^{556}$

\section{Metal component manufacturing}

Several studies have reported a link between metal component manufacture and gastric cancer. ${ }^{57}{ }^{58}$ This seems to be associated with use of cutting oils or the mist generated during manufacture. ${ }^{59}$ These contain polycyclic aromatic hydrocarbons some of which are carcinogens. This link has not been supported in all studies, ${ }^{606}$ some of which failed to provide information on levels of exposure or used small samples of employees. It is clear that further detailed research is necessary.

\section{Tin miners}

Tin mines in the UK are known to have the highest concentrations of radon in Britain. ${ }^{62}$ A study of 1333 miners in Cornish tin mines reported an increased risk of death from gastric cancer (standard mortality rate $=141$ ), especially among underground workers..$^{63}$ The study attributed the risk to physical activity and exposure to dust ${ }^{64}$ A later study analysed mortality in a cohort of 3082 UK tin miners from 1941-86 and found the incidence of gastric cancer was increased by $40 \% .^{65}$ There was no relation to time spent underground. Cancer of the stomach was, however, associated with exposure to arsenic, an important byproduct of some tin mines.

\section{Other miners}

Studies on Ontario goldminers by Kusiak et al demonstrated an excess mortality from gastric cancer ${ }^{32}$; this was possibly due to exposure to mineral dust and chromium. There was some evidence that place of birth could be a further risk for certain age groups. A cohort study of miners from Kalgoorlie in Australia and other studies on gold miners in South Africa ${ }^{66}$ and France, ${ }^{67}$ however, have not shown a significant association with gastric cancer.

\section{COAL INDUSTRY WORKERS}

Coal contains a number of carcinogens including polyaromatic hydrocarbons, cadmium, chromium, etc. ${ }^{68}$

In 1961, Stocks analysed data from the Registrar General's Decennial Supplements of Occupational Mortality. ${ }^{69}$ Gastric cancer was one of the six commonest causes of mortality in coal workers. Enterline reported similar findings in the USA ${ }^{70}$ and Rockette concluded that it is one of the three commonest causes of death in coal miners. ${ }^{71}$

Other studies have supported this view ${ }^{72-75}$ but others have failed to confirm these findings. ${ }^{76-79}$ Most studies are retrospective and have to deal with a number of confounding factors. Another possible reason may be inaccuracies in recording systems, including variation between a deceased person's occupation as determined by other sources of employment information and data from death certificates.

The risk of gastric cancer in coal mining is real but remains to be quantified. Conflicting results may be explained by the variability of other confounding factors such as diet, smoking, lifestyle, etc. A recent study investigated the value of screening for gastric cancer in a group of more than 2000 coal miners in Nottinghamshire. ${ }^{80}$ They had a high incidence of gastrointestinal symptoms, acute and chronic gastritis, and intestinal metaplasia. The results suggested they would be a suitable group for screening for malignant and premalignant lesionsthat is, intestinal metaplasia, dysplasia, and chronic gastritis.

\section{CHEMICAL INDUSTRY WORKERS \\ Oil refinery workers}

Workers in oil refineries are in regular contact with known carcinogens, such as polyaromatic hydrocarbons. This has led to several studies over the last two decades. ${ }^{81-83}$

Rushton and Alderson studied a cohort of over 34000 employees in eight UK refineries for the years $1950-75 .{ }^{82}$ Cancer mortality, compared with the average British male mortality with adjustment for regional variations, was lower due to reduced lung cancer deaths. This was attributed to smoking restrictions at work, although smoking habits were not investigated. Gastric cancer risk was raised in four of the refineries affecting mostly labourers with long service. During a 15 year follow up Rushton noted that the "all cancer" deficit persisted due to a reduced incidence of lung cancer. ${ }^{84}$ Gastric malignant neoplasms were again raised in number, mainly in operators and labourers.

Two studies from Canada found a significant incidence of gastric cancer, ${ }^{83} 85$ as did a survey from 39 USA petroleum counties ${ }^{86}$ It was suggested that petroleum and its byproducts might pose an increased risk to employees as well as to the surrounding communities but further research is needed.

\section{Other chemical workers}

A population survey of 17000 patients admitted to Roswell Park Memorial Hospital, New York suggested an increased risk among chemical industry operatives ${ }^{87}$ The risk was highest among the young (relative risk $=11$ ), particularly for those with at least five years of exposure. Data on the levels of exposure were not available. There are also reports which suggest there may be an increased risk in the azo dye industry. ${ }^{88}$

\section{RUBBER AND LEATHER PRODUCT INDUSTRY WORKERS}

\section{Rubber industry workers}

Rubber manufacturing involves many agents that are well recognised carcinogens and during manufacture there is considerable exposure to nitrosamines. ${ }^{35}$

In 1982 the IARC accepted there was a risk of stomach cancer in the rubber industry. ${ }^{89}$ This was supported by data from the British Rubber Manufacturer's Association (BRMA) study ${ }^{90}$ and the USA, ${ }^{91}{ }^{92}$ particularly in jobs related to the early stages in processing. Some reports from Italy and Sweden did not support this view. ${ }^{93}$ However, a follow up of the BRMA cohort by Sorahan et $a l^{94}$ and a study by Coggon et a ${ }^{95}$ reaffirmed the risk.

\section{Leather and shoe industry workers}

Workers in this industry are exposed to several carcinogens, such as chromium and chlorophenols. Studies from the UK in the 1950s reported an increased risk. A later British study found no excess of gastric cancer mortality among tanners, ${ }^{96}$ although in Sweden there was a slightly increased incidence in 600 tannery employees. ${ }^{97}$ The IARC accepts that there is some evidence of increased risk among boot and shoemakers. ${ }^{98}$

\section{WOOD PRODUCT INDUSTRY WORKERS}

Population studies such as the Washington State survey based on 430000 death certificates, found a significant risk for carpenters, loggers, plywood workers, and cabinet makers. ${ }^{99}$ Other studies have produced similar results. ${ }^{100}$

While carpenters have been shown to have a high risk of gastric cancer, ${ }^{99} 101$ data on other wood related occupations including pulp and paper mill workers, ${ }^{102}{ }^{103}$ furnishers, cabinet makers, foresters, loggers, wood model makers, etc are less consistent. A large Danish study examined 65000 cancer 
cases and found a twofold increase in the risk of gastric cancer related to occupations in basic wood processing. ${ }^{104}$ This was attributed to social factors, because there was no correlation with sinonasal cancer rates.

However, lack of details on social history, diet, and other habits that act as confounding factors make it difficult to arrive at clear conclusions.

\section{WORKERS IN THE UTILITIES \\ Coking plant workers}

A study of over 4900 workers in a gas-producing coke plant demonstrated a high risk of gastric cancer and the trend was confirmed by a similar Dutch study. ${ }^{105} 106$

\section{AGRICULTURE AND LAND WORKERS}

Farmers may have an increased risk of gastric cancer because of their contact with fertilisers. However, studies on the mortality of nitrate fertiliser workers do not support this hypothesis, ${ }^{107-109}$ despite high concentrations of nitrate in their saliva. An occupational study of over 52000 patients from Japan detected a significant cancer risk for agricultural workers. ${ }^{110}$ Some studies have linked gastric cancer with specific groups such as grain farmers in China, ${ }^{111}$ and farm labourers in Italy, $^{112}$ but these results have not been confirmed. ${ }^{113}$

\section{FOOD INDUSTRY WORKERS \\ Fishermen}

A study from Sweden detected a significantly increased risk of gastric cancer among Baltic Sea fishermen. ${ }^{114}$ Dietary factors (high smoked food and low vegetable intake) were thought responsible for this excess risk. A similar high incidence of gastric cancer was also found among diver-fishermen in Singapore. ${ }^{115}$

\section{TRANSPORT WORKERS}

\section{Drivers}

Particles emitted from petroleum and diesel engines contain numerous polycyclic aromatic hydrocarbons which are mutagenic and carcinogenic in several animal species.

Stomach and other gastrointestinal tract cancers are commoner among Geneva's professional drivers. ${ }^{116}$ Risk was related to exposure to exhaust gas and fumes but there was no relation to the time of first exposure, although the numbers were small.

Similar findings have been reported from a longitudinal study of London drivers. ${ }^{117}$ Those affected mostly were lorry and coach drivers.

\section{MISCELLANEOUS OCCUPATIONS \\ Jewellery workers}

A death certificate based study of 931 men from Massachusetts, USA who died from 1957-75 suggested an excess of gastric cancer. ${ }^{118}$ Although it is known that some of the abrasives used in the trade are carcinogens, the sample size was rather small and further studies are needed.

\section{OCCUPATIONAL POPULATION STUDIES}

Population studies provide a broad picture but difficulties can arise in interpretation because of multiple comparisons and lack of exposure data.

Olsen and Jensen in a Danish cancer registry study analysed approximately 93000 cancer cases. ${ }^{119}$ There was a high incidence of gastric cancer among workers in utilities (electricity, gas, and water), employees of the wood trade, and those in fishing, agriculture, and forestry occupations.

A cancer registry based case-control study from New Zealand examined 22 occupational groups and found an increased risk of gastric cancer in forestry workers, field crop workers, grain millers and related workers, brewers, and beverage makers. ${ }^{120}$

Kneller et al examined data on over 13000 cases of gastric cancer from Shanghai, China and found an increased risk in "dusty industries" which included foundry workers, cement workers, coal miners, textile machine operators, wood workers and grain farmers. ${ }^{111}$ In addition, there was a "high temperature" group which included employees working near open fossil fuel combustion sources. This group included metal smelting/refining furnacemen, blacksmiths, railway engine drivers, boilermen, and firemen. Most have been reported at increased risk in earlier studies.

A Spanish study found increased risks for wood and furniture workers, construction workers, and glass and ceramic workers. $^{72}$

\section{DISCUSSION}

The search for links between occupation and gastric cancer has been intensive and wide ranging. The IARC recently considered that there is evidence, although not definitive, of an association between gastric cancer and coal, rubber, and leather industries and asphalt workings. ${ }^{98}$

Early studies suffered some weaknesses but have generated hypotheses and outlined directions of research. Some of the reasons preventing definite conclusions are:

- Most studies are based on job titles. This has obvious flaws not least because the job content of a particular title may vary.

- Dose-response relationship has not been established in most studies. Occupations known to have a high risk of cancer do not have agreed minimum safe doses. When "safe dose" exposure exists, it is often arbitrary.

- Individual occupational history data are limited in most studies.

- Changes in work practice and therefore levels and type of exposure are almost impossible to establish. There is also a degree of mobility in the labour force within some industries which could lead to significant changes in levels of exposure.

Despite their methodological weaknesses, many studies have led to improved safety standards and exposure to suspect agents has been reduced. Effects of low level exposure are more difficult to identify. The situation becomes more complex if environmental exposure is also taken into account. For example, the use of talc in the preparation of rice and sugar confectionery has been partially incriminated in the development of gastric cancer in Japan.

Despite the absence of clearly defined associations between gastric cancer and some occupations, there is an undeniable trend in certain groups-for example, dusty occupations and work in high temperature environment.

The relation of gastric cancer to dusty occupations has been the focus of significant research. A cancer registry survey from California showed that exposure to occupational dust, particularly mineral and organic dusts, was an independent risk factor for gastric carcinoma. ${ }^{121}$ Wright et al suggested that dust particles have an abrasive effect on the gastric mucosa. ${ }^{121}$ Alternative ways by which occupational dust could promote gastric cancer is through absorption and delivery of carcinogens such as N-nitrosamines to the stomach.

Findings from another study in Stoke-on-Trent, UK did not support the general "dust" hypothesis. ${ }^{95}$ This study concentrated on the rubber, steel and iron industries, coalmining, and ceramics. The results suggested an association with rubber manufacture but only a weak association with other industries.

Inhaled noxious dust is expelled from the airways by an intact respiratory epithelium and then swallowed. Meyer suggested that non-smokers in dusty industries may be at a 
higher risk of gastric cancer, ${ }^{122}$ because their respiratory epithelium is more efficient at clearing airways, resulting in a higher load in the stomach. In smokers, this mechanism is impaired, hence a lower risk of gastric cancer despite a higher risk of lung cancer. In contrast Ames and Gamble suggested an alternative hypothesis. ${ }^{123}{ }^{124}$ They identified a higher risk among smokers and felt that prolonged exposure to coal dust and smoking overwhelms some unspecified defence mechanism, which then allows gastric carcinogenesis to proceed. Smoking and coal dust may have a synergistic effect, interacting locally to promote gastric carcinogenesis by enhancing nitrosation, although each is not sufficient alone to cause cancer. ${ }^{74}{ }^{122}$

Stukonis and Doll found the amount of physical activity at work correlated strongly with gastric cancer mortality ${ }^{64}$ This only applied to social class III individuals. The trend was less clear among other social classes and cancers at other sites. One explanation is that people who work physically hard need to eat more often and in larger quantities, exposing themselves to more carcinogens in their food.

Dose-response relationships remain undefined for most suspected carcinogens. Mechanisms of action are unknown and may be related to mutagenic potential. A possible mechanism proposed by Cairns is that a high rate of mitoses leads eventually to survival of aberrant cells by overwhelming regulatory mechanisms. ${ }^{47} 125$

There is little doubt that chance associations with gastric cancer have resulted from the complexity of confounding factors operating in many occupational environments. It would be difficult to judge with confidence whether some people are more at risk as a result of their occupation or their social class, when some occupations attract workers from certain classes and indeed occupations define social classes. On the other hand, although there is an accepted link between social class and gastric cancer, the role of social class may have been overemphasised, particularly as many studies do not provide data on social confounders.

Occupation and therefore socioeconomic status may also be an important determinant of extent and survival in cancer. ${ }^{9}$ This may be a reflection of early or late detection, nutritional intake, and quality of care.

Establishing gastric cancer as an occupational hazard could have a substantial impact. Asbestos related lung cancer is an example that has had significant social, financial, and legal consequences. Regardless of how weak the link with occupation is, it may not prevent claims being pursued. ${ }^{126}$

Does occupational screening for gastric cancer have a place at work? Japan has a long established and rewarding experience of mass population gastric surveys since 1953, using primarily barium studies and endoscopy. ${ }^{127}{ }^{128}$ Efforts to assess the benefit in occupational groups such as miners through identification of precursor lesions in "dyspepsia" clinics may provide a model for screening. If serological methods of screening are also developed, occupational screening could come a step closer.

\section{Authors' affiliations}

A Raj, J F Mayberry, Gastrointestinal Research Unit, Leicester General Hospital

T Podas, Thessalonika, Greece

\section{REFERENCES}

1 Alexander HR, Kelsen DP, Tepper JE. Cancer of the stomach. In: DeVita VT Jr, Hellman S, Rosenberg SA, eds. Cancer: principles and practice of oncology. 4th Ed. Philadelphia: JB Lippincott, 1993.

2 Parkin D, Läära E, Muir C. Estimates of the worldwide frequency of sixteen major cancers in 1980. Int J Cancer 1988:41:184-97.

3 Parkin DM, Pisani P, Ferlay. Estimates of the worldwide incidence of eighteen major cancers in 1985. Int J Cancer 1993;54:594-606.
4 Waterhouse J, Muir C, Correa $\mathrm{P}$, et al, eds. Cancer incidence in five continents. Vol 3. IARC Scientific Publication No 15. Lyon: International Agency for Research on Cancer, 1976.

5 Haenszel W, Kurihara M, Segi $M$, et al. Stomach cancer among Japanese in Hawaii. J Natl Cancer Inst 1972;49:969-88.

6 Correa P, Haenszel W, Tannenbaum S. Epidemiology of gastric carcinoma: review and future prospects. Nat Cancer Inst Monogr 1982;62:129-34

7 Zacho A, Neilson J, Cederqvist C. Relationship between type of tobacco used and localisation of tumour in patients with gastric cancer. Acta Chir Scand 1975:141:676-9.

8 Torgersen 0 , Petersen $M$. The epidemiology of gastric cancer in Oslo: cartographic analysis of census tracts and mortality rates of sub-standard housing areas. Br J Cancer 1956;10:299-306.

9 Kato I, Tominaga S, Ikari A. The role of socioeconomic factors in the survival of patients with gastrointestinal cancers. Jpn J Clin Oncol 1992;22:270-7.

10 Lyon JL, Klauber MR, Gardner JW, et al. Cancer incidence in Mormons and non-Mormons in Utah 1966-1970. N Engl J Med 1976;294:129-33.

11 Griffith GW. The sex ratio in gastric cancer and hypothetical considerations relative to aetiology. Br J Cancer 1968;22:163-72.

12 Ashley DJB. Gastric cancer in Wales. J Med Genet 1969;6:76-9.

13 Waterhouse J, Muir C, Shanmugaratnam K, et al. Cancer incidence in five continents. Vol IV. IARC Scientific publication No 42. Lyon: International Agency for Research on Cancer, 1982.

14 Aird I, Bentall H, Roberts JAF. A relationship between cancer of the stomach and the ABO blood groups. BM 1953;i:799-801

15 Glober GA, Cantrell EG, Doll R, et al. Interaction between $A B O$ and rhesus blood groups, the site of origin of gastric cancers, and the age and sex of the patient. Gut 1971;12:570-3.

16 Macklin CM. Inheritance of cancer of the stomach and large intestine in man. J Natl Cancer Inst 1960;24:551-71.

17 Woolf CM. A further study on the familial aspects of carcinoma of the stomach. Am J Hum Genet 1956;8:102-9.

18 Graham S, Lilienfeld AM. Genetic studies of gastric cancer in humans: an appraisal. Cancer 1958;11:945-58.

19 Correa P, Cuello C, Duque E. Carcinoma and intestinal metaplasia of the stomach in Colombian migrants. J Natl Cancer Inst 1970;44:297-306.

20 Haas JF, Schottenfeldt D. Epidemiology of gastric cancer. In: Lipkin M, ed. Gastrointestinal tract cancer. New York: Plenum Press, 1978: 173-206.

21 Correa P, Haenzel W, Cuello C, et al. A model for gastric cancer epidemiology. Lancet 1975;ii:58-60.

22 Nomura A, Stemmermann GN, Chyou P-H, et al. Helicobacter pylori infection and gastric carcinoma among Japanese Americans in Hawaii. N Engl J Med 1991;325:1132-6.

23 Parsonnet J, Friedman GD, Vandersteen DP, et al. Helicobacter pylori infection and the risk of gastric carcinoma. N Engl J Med 1991;325:1127-31.

24 Correa P, Haenszel W, Cuello C, et al. Gastric precancerous process in a high risk population: cross-sectional studies. Cancer Res 1990;50:4731-6.

25 Correa P, Sassano N, Stemmermann GN, et al. Pathology of gastric carcinoma in Japanese populations: comparisons between Miyag Prefecture, Japan and Hawaii. J Natl Cancer Inst 1973;51:1449-59.

26 Muñoz N, Matko I. Histological types of gastric cancer and its relationship with intestinal metaplasia. Cancer Res 1972;39:99-105.

27 Torrado J, Correa P, Ruiz B, et al. Prospective study of Lewis antigens in the gastric precancerous process. Cancer Epidemiol Biomarkers Prev 1992;1:199-205.

28 Lauren $\mathbf{P}$. The two histological main types of gastric carcinoma. Diffuse and so called intestinal carcinoma. Acta Pathologica et Microbiolica Scandinavica 1965:64:31-49.

29 Ribeiro MM, Sarmento JA, Sobrinho Simoes MA, et al. Prognostic significance of Lauren and Ming classifications and other pathologic parameters in gastric carcinoma. Cancer 1981:47:780-4.

30 Muñoz N, Connelly R. Time trends of intestinal and diffuse types of gastric cancer in the United States. Int J Cancer 1971;8:158-64.

31 Munoz N, Correa P, Cuello C, et al. Histologic types of gastric carcinoma in high-and low-risk areas. Int J Cancer 1968;3:809-18.

32 Kusiak RA, Ritchie AC, Springer J, et al. Mortality from stomach cancer in Ontario miners. Br J Ind Med 1993:50:117-26.

33 Risch HA, Jain M, Choi NW, et al. Dietary factors and the incidence of Risch HA, Jain M, Choi NW, et al. Dietary factors and the
cancer of the stomach. Am J Epidemiol 1985:122:947-59.

34 Correa P. Human gastric carcinogenesis: a multistep and multifactorial process - first American Cancer Society Award Lecture on Cancer Epidemiology and Prevention. Cancer Res 1992;52:6735-40.

35 Tricker AR, Spiegelhalder B, Preussman R. Environmental exposure to preformed nitroso compounds. Cancer Surveys 1989:8:251-72.

36 Magee PN, Barnes JM. Carcinogenic nitroso compounds. Adv Cancer Res 1967:10:163-246.

37 Mirvish SS. Kinetics of nitrosamide formation from alkylureas, n-alkyurethane and alkyl-guanidines: possible implications for the etiology of human gastric cancer. J Natl Cancer Inst 1971;46:1 183-93.

38 Fine DH, Lieb D, Rufeh F. Principle of operation of the Thermal Energy Analyser (TEA) for the trace analysis of volatile and non-volatile $\mathrm{N}$-nitroso compounds. J Chromatogr 1975;107:351-7.

39 Mirvish SS. Formation of $\mathrm{N}$-nitrosocompounds: chemistry, kinetics and in vivo occurrence. Toxicol Appl Pharmacol 1975;31:325-51.

40 Tannenbaum SR, Weisman M, Fett D. The effect of nitrate intake on nitrite formation in human saliva. Food Cosmet Toxicol 1976;14:549-52 
41 Ames BN, Gold LS. Too many rodent carcinogens: mitogenesis increases mutagenesis. Science 1990:249:970-1.

42 Browne K. Asbestos related malignancy and the Cairns hypothesis [editorial]. Br J Ind Med 1991;48:73-6.

43 Mossman BT. Mechanisms of asbestos carcinogenesis and toxicity: the amphibole hypothesis revisited. Br J Ind Med 1993;50:673-6.

44 Heasman MA, Lipworth L. Accuracy of certification of cause of death. GRO studies on medical and population subjects No 20. London: HMSO 1966 .

45 Selikoff IJ, Hammond EC, Seidman H. Mortality experience of insulation workers in the United States and Canada. Ann N Y Acad Sci 1979;330:91-116.

46 Newhouse ML, Wagner JC. Validation of death certificates in asbestos workers. Br J Ind Med 1969;26:302-7.

47 International Agency for Research on Cancer. IARC monographs on the evaluation of the carcinogenic risk of chemicals to humans. Vol 34. Polynuclear aromatic compounds. Part 3 industrial exposures in aluminiun production, coal gasification, coke production and iron and steel founding. Lyon: IARC, 1984

48 Sorahan T, Cooke MA. Cancer mortality in a cohort of United Kingdom steel foundry workers: 1946-85. Br J Ind Med 1989;46:74-81

49 Sorahan T, Faux AM, Cooke MA. Mortality among a cohort of United Kingdom steel foundry workers with special reference to cancers of the stomach and lung, 1946-90. Occup Environ Med 1994;51:316-322.

50 International Agency for Research on Cancer. IARC monographs on the evaluation of carcinogenic risks to humans, supplement 7 . Overall evaluations of carcinogenicity: an updating of IARC monographs volumes 1-42. Lyon: IARC, 1987: 100-6.

51 Barton RT, Hogetveit AC. Nickel-related cancers of the respiratory tract. Cancer 1980:45:3061-4.

52 International Committee on Nickel Carcinogenesis in Man. Report. Scand J Work Environ Health 1990;16:1-81.

53 Karjalainen S, Keritula R, Pukkala E. Cancer risk among workers at a copper/nickel smelter and nickel refinery in Finland. Int Arch Occup Environ Health 1992;63:547-51.

54 Cooper WC, Wong O, Kheifets L. Mortality among employees of lead battery plants and lead producing plants, 1947-1980. Scand J Environ Health 1985:11:331-45.

55 Malcolm D, Barnett H. A mortality study of lead workers 1925-1976. Br $J$ Ind Med 1982;30:404-10.

56 Michaels D, Zoloth SR, Stern FB. Does low-level lead exposure increase risk of death? A mortality study of newspaper printers. Int J Epidemiol 1991;20:978-83.

57 Silverstein $M$, Park R, Marmor M, et al. Mortality among bearing plant workers exposed to metal working fluids and abrasives. J Occup Med 1988;30:706-13

58 Park RM, Wegman DH, Silverstein MA, et al. Causes of death among workers in a bearing manufacturing plant. $\mathrm{Am} \mathrm{J}$ Ind Med 1988:13:569-80.

59 Järvholm BJ, Lavenius B. Mortality and cancer morbidity in workers exposed to cutting fluids. Arch Environ Health 1987;42:361-5.

60 Decoufle P. Further analysis of cancer mortality patterns among workers exposed to cutting oil mists. J Natl Cancer Inst 1978;61:1025-30.

61 Acquavella J, Leet T, Johnson G. Occupational experience and mortality among a cohort of metal components manufacturing workers. Epidemiology 1993;4:428-34.

62 Strong JC, Laidlaw AJ, O'Riordan MC. Radon and its daughters in various British mines. Clinton: National Radiological Protection Board, 1975 (NRPB publication No R39)

63 Fox AJ, Goldblatt P, Kinlen LJ. A study of the mortality of Cornish tin miners. Br J Ind Med 1981;38:378-80.

64 Stukonis M, Doll R. Gastric cancer in man and physical activity at work. Int J Cancer 1969:4:248-54

65 Hodgson JT, Jones RD. Mortality of a cohort of tin miners 1941-86. Br J Ind Med 1990;47:665-76.

66 Wyndham CH, Bezuidenhout BN, Greenacre M, et al. Mortality of middle-aged white South African gold miners. $\mathrm{Br} J$ Ind Med 1986:43:677-84

67 Simonato L, Ferro G, Winkelman R, et al. A mortality study of miners and factory workers at the "societe de mines et produits chimiques de Salsigne", France. Lyon: International Agency for Research on Cancer, World Health Organisation.

68 Whong W-Z, Long R, Ames RG, et al. Role of nitrosation in the mutagenic activity of coal dust: a postulation for gastric carcinogenesis in coal miners. Environ Res 1983:32:298-304.

69 Stocks P. On the death rates from cancer of the stomach and respiratory diseases in 1949-53 among coal miners and other male residents in counties of England and Wales. Br J Cancer 1962:16:592-8.

70 Enterline PE. Mortality rates among coal miners. Am J Public Health 1964;54:758-68.

71 Rockette H. Cause-specific mortality of coal miners. J Occup Med 1977:19.795-801.

72 Matolo NM, Klauber MR, Gorishek WM, et al. High incidence of gastric carcinoma in a coal mining region. Cancer 1972;29:733-7.

73 González C, Sanz M, Marcos G, et al. Occupation and gastric cancer in Spain. Scand J Work Environ Health 1991;17:240-7.

74 Creagan E, Hoover R, Fraumeni J. Mortality from stomach cancer in coal mining regions. Arch Environ Health 1974;28:28-30.

75 Craven JL, Baum M, West RR. Variations in gastric cancer incidence in South Wales. Clin Oncol 1979:5:341-51.

76 Davies J. Stomach cancer mortality in Worksop and other Nottinghamshire mining towns. BrJ Cancer 1980;41:438-45.
77 Swaen GMH, Aerdts CWHM, Slangen JJM. Gastric cancer in coalminers: final report. Br J Ind Med 1987:44:777-9.

78 Swaen GMH, Aerdts CWHM, Sturmans F, et al. Gastric cancer in coal miners: a case- control study in a coal mining area. $\mathrm{Br} J$ Ind Med 1985;42:627-30

79 Falk HL, Jurgelski W. Health effects of coal mining and combustion: carcinogens and cofactors. Environ Health Perspect 1979;33:203-26.

80 Harrison JD, Morris DL, Hardcastle JD. Screening for gastric carcinoma in coal miners. Gut 1993;34:494-8.

81 Hanis NM, Shallenberger LG, Donaleski DL, et al. A retrospective mortality study of workers in three major US refineries and chemical plants part I: comparison with US population. J Occup Med 1985;27:283-92.

82 Rushton L, Alderson MR. An epidemiological survey of eight oil refineries in Britain. Br J Ind Med 1981;38:225-34

83 Hanis NM, Stavraky KM, Fowler JL. Cancer mortality in oil refinery workers. J Occup Med 1979;21:167-74.

84 Rushton L. Further follow up of mortality in a United Kingdom oil refinery cohort. Br J Ind Med 1993;50:549-60.

85 Theriault G, Provencher S. Mortality study of oil refinery workers: five-year follow-up. J Occup Med 1987;29:357-60.

86 Blot WJ, Brinton LA, Fraumeni LF, et al. Cancer mortality in US counties with petroleum industries. Science 1977;198:51-3.

87 Viadana E, Bross IDJ, Houten L. Cancer experience of men exposed to inhalation of chemicals or to combustion products. J Occup Med 1976;18:787-92.

88 Delzell E, Macaluso M, Cole P. A follow-up study of workers at a dye and resin manufacturing plant. J Occup Med 1989;31:273-8.

89 International Agency for Research on Cancer. IARC monographs on the evaluation of carcinogenic risks to humans. Vol 28. The rubber industry. Lyon: IARC, 1982

90 Parkes HG, Veys CA, Waterhouse JAH. Cancer mortality in the British rubber industry. Br J Ind Med 1982;29:209-20.

91 McMichael AJ, Spirtas R, Kupper LL. An epidemiologic study of mortality within a cohort of rubber workers. J Occup Med 1974;16:458-64.

92 Monson RR, Fine L. Cancer mortality and morbidity among rubber workers. J Natl Cancer Inst 1978;61:1047-53.

93 Gustavsson P, Hogstedt C, Holmberg B. Mortality and incidence of cancer among Swedish rubber workers, 1952-1981. Scand J Work Environ Health 1986;12:538-44

94 Sorahan T, Parkes HG, Veys CA, et al. Mortality in the British rubber industry 1946-85. Br J Ind Med 1989;46:1-11

95 Coggon D, Barker DJP, Cole RB. Stomach cancer and work in dusty industries. Br J Ind Med 1990;47:298-301.

96 Pippard EC, Acheson ED, Winter PD. Mortality of tanners. Br J Ind Med 1985;42:285-7.

97 Edling $\mathrm{C}$, Kling $\mathrm{H}$, Flodin $U$, et al. Cancer mortality among leathe tanners. BrJ Ind Med 1986;43:494-6.

98 International Agency for Research on Cancer. IARC monographs on the evaluation of carcinogenic risks to humans. Vol 25. Wood, leather and some associated industries. Lyon: IARC, 1981

99 Milham S. Occupational mortality in Washington state, 1950-79. Washington, DC: US Department of Health and Human Services, 1983 (DHSS (NIOSH), Publication No 83-1 16).

100 Dubrow R, Wegman DH. Cancer and occupation and Massachusetts: death certificate study. Am J Ind Med 1984;6:207-30.

101 Lindsay JP, Stavraky KM, Howe GR. The Canadian Labour Force ten percent sample study. J Occup Med 1993:35:408-14.

102 Wingren $\mathbf{G}$, Kling $\mathrm{H}$, Axelson $\mathrm{O}$. Gastric cancer among paper mill workers. J Occup Med 1985;27:715.

103 Bross IDJ, Viadana E, Houten L. Occupational cancer in men exposed to dust and other environmental hazards. Arch Environ Health 1978;33:300-7.

104 Olsen JH, Moller H, Jensen OM. Risks for respiratory and gastric cancer in wood- working occupations in Denmark. J Cancer Res Clin Oncol $1988 ; 114: 420-4$

105 Berger J, Manz A. Cancer of the stomach and the colon-rectum in a coke gas plant. Am J Ind Med 1992;22:825-34.

106 Swaen GMH, Slangen JJM, Volovics A, et al. Mortality of coke plant workers in the Netherlands. Br J Ind Med 1991;48:130-6.

107 Al-Dabbagh S, Forman D, Bryson D, et al. Mortality of nitrate fertiliser workers. Br J Ind Med 1986;43:507-15.

108 Hagmar L, Bellander T, Andersson C, et al. Cancer morbidity in nitrate fertiliser workers. Int Arch Occup Environ Health 1991;63:63-7.

109 Fandrem SI, Kjuus H, Andersen A, et al. Incidence of cancer among workers in a Norwegian nitrate fertiliser plant. Br J Ind Med 1993:50:647-52

110 Kato I, Tominaga S, Ikari A. An epidemiological study on occupation and cancer risk. Jpn J Clin Oncol 1990;20:121-7.

111 Kneller RW, Gao YT, McLaughlin JK, et al. Occupational risk factors for gastric cancer in Shanghai, China. Am J Ind Med 1990;18:69-78.

112 Cocco PL, Palli D, Buiatti E, et al. Occupational exposures as risk factors for gastric cancer. Cancer Causes Control 1994;5:241-8.

113 Ronco G. Costa G, Lynge E. Cancer risk among Danish and Italian Ronco G, Costa G, Lynge E. Cancer risk
farmers. Br J Ind Med 1992;49:220-5.

114 Hagmar L, Lindén K, Nilsson A, et al. Cancer incidence and mortality among Swedish Baltic Sea fishermen. Scand J Work Environ Health 1992;18:217-24

115 Jeyaratnam J, Lee J, Phoon WO. Stomach cancer incidence in a cohort of fishermen in Singapore. Scand J Work Environ Health 1987:13:524-6.

116 Gubéran E, Usel M, Raymond L, et al. Increased risk for lung cancer and for cancer of the gastrointestinal tract among Geneva professional drivers. Br J Ind Med 1992;49:337-44. 
117 Balarajan R, McDowall ME. Professional drivers in London: a mortality study. Br J Ind Med 1988:45:483-6.

118 Sparks PJ, Wegman DH. Cause of death among jewellery workers. J Occup Med 1980;22:733-6.

119 Olsen JH, Jensen OM. Occupation and risk of cancer in Denmark: an analysis of 93,810 cancer cases, 1970-1979. Scan J Work Environ Health 1987:13(suppl 1): 1-91.

120 Dockerty JD, Marshall S, Fraser J, et al. Stomach cancer in New Zealand: time trends, ethnic group differences and a cancer registry-based case-control study. Int J Epidemiol 1991;20:45-53.

121 Wright WE, Bernstein L, Peters JM, et al. Adenocarcinoma of the stomach and exposure to occupational dust. Am J Epidemiol 1988; 128:64-73.
122 Meyer MB, Luh GD, Sotelo JM, et al. Hypothesis: the role of the lung in stomach carcinogenesis. Am Rev Respir Dis 1980;1 21:887-92.

23 Ames RG. Gastric cancer and coal mine dust exposure. Cancer 1983:52:1346-50.

124 Ames RG, Gamble JF. Lung cancer, stomach cancer, and smoking status among coal miners. Scand J Work Environ Health 1983;9:443-8.

125 Cairns J. Mutation selection and the natural history of cancer. Nature 1975;255: 197-200.

126 Halnan K. Failure to substantiate two cases of alleged occupational radiation carcinogenesis. Lancet 1988;i:639.

127 Kaneko E, Nakamura T, Uneda N, et al. Outcome of gastric carcinoma detected by gastric mass survey in Japan. Gut 1977;18:626-30.

128 Okui K, Tejima H. Evaluation of gastric mass survey. Acta Chir Scand 1980;146:185-7.

\section{Clinical Evidence-Call for contributors}

Clinical Evidence is a regularly updated evidence based journal available worldwide both as a paper version and on the internet. Clinical Evidence needs to recruit a number of new contributors. Contributors are health care professionals or epidemiologists with experience in evidence based medicine and the ability to write in a concise and structured way.

Currently, we are interested in finding contributors with an interest in the following clinical areas:

Altitude sickness; Autism; Basal cell carcinoma; Breast feeding; Burns; Carbon monoxide poisoning; Cervical cancer; Chronic renal failure; Cystic fibrosis; Ectopic pregnancy; Emphysema; Grief/bereavement; Halitosis; Hodgkins disease; Infectious mononucleosis (glandular fever); Jet lag; Kidney stones; Malignant melanoma (metastatic); Mesothelioma; Myeloma; Ovarian cyst; Pancreatitis (acute); Pancreatitis (chronic); Polycystic ovaries; Polymyalgia rheumatica; Post-partum haemorrhage; Pulmonary embolism; Recurrent miscarriage; Repetitive strain injury; Scoliosis; Seasonal affective disorder; Squint; Systemic lupus erythematosus; Testicular cancer; Uterine prolapse; Varicocele; Viral meningitis; Vitiligo

However, we are always looking for others, so do not let this list discourage you.

Being a contributor involves:

- Appraising the results of literature searches (performed by our Information Specialists) to identify high quality evidence for inclusion in the journal.

- Writing to a highly structured template (about 2000-3000 words), using evidence from selected studies, within 6-8 weeks of receiving the literature search results.

- Working with Clinical Evidence Editors to ensure that the text meets rigorous epidemiological and style standards.

- Updating the text every eight months to incorporate new evidence.

- Expanding the topic to include new questions once every 12-18 months.

If you would like to become a contributor for Clinical Evidence or require more information about what this involves please send your contact details and a copy of your CV, clearly stating the clinical area you are interested in, to Claire Folkes (cfolkes@bmigroup.com).

\section{Call for peer reviewers}

Clinical Evidence also needs to recruit a number of new peer reviewers specifically with an interest in the clinical areas stated above, and also others related to general practice. Peer reviewers are health care professionals or epidemiologists with experience in evidence based medicine. As a peer reviewer you would be asked for your views on the clinical relevance, validity and accessibility of specific topics within the journal, and their usefulness to the intended audience (international generalists and health care professionals, possibly with limited statistical knowledge). Topics are usually 2000-3000 words in length and we would ask you to review between 2-5 topics per year. The peer review process takes place throughout the year, and our turnaround time for each review is ideally 10-14 days.

If you are interested in becoming a peer reviewer for Clinical Evidence, please complete the peer review questionnaire at www.clinicalevidence.com or contact Claire Folkes (cfolkes@bmigroup.com). 